Review Article

www.ijrap.net

\title{
TRADITIONAL USES, PHYTOCHEMICAL AND PHARMACOLOGICAL ASPECTS OF EMILIA SONCHIFOLIA (L.) DC
}

Dash Gouri Kumar*, Abdullah Mohd. Syafiq and Yahaya Ruhaiyem

Faculty of Pharmacy and Health Sciences, Universiti Kuala Lumpur Royal College of Medicine Perak, Ipoh, Perak, Malaysia

Received on: 24/04/15 Revised on: 18/05/15 Accepted on: 09/06/15

\author{
*Corresponding author \\ Dr. Gouri Kumar Dash, Professor and Head (Research and Post Graduate Studies), Faculty of Pharmacy and Health Sciences, Universiti Kuala \\ Lumpur Royal College of Medicine Perak, 30450 Ipoh, Perak, Malaysia. Email: gkdash2@gmail.com
}

DOI: $10.7897 / 2277-4343.064103$

\begin{abstract}
Emilia sonchifolia (L.) DC (Family: Asteraceae), commonly known as 'lilac tasselflower' is an important edible medicinal plant found to be used as one of the popular ingredients of traditional vegetable salads in Malaysia, Bangladesh and India. In addition to its use as a vegetable, the plant is documented in ethnomedicine to possess several medicinal benefits in treating night blindness, epilepsy, fever and inflammatory diseases, malaria, asthma, liver diseases, eye inflammation, influenza, burns and breast abscesses. The pharmacological studies have shown that the plant possesses numerous notable biological activities such as antimicrobial, analgesic, antiinflammatory, antioxidant, anticancer, antidiabetic, hepatoprotective, antianxiety, anticataract and anticonvulsant activities. A few phytoconstituents have been isolated from the plant. The plant is rich with flavonoids. Presence of pyrrolizidine alkaloids have been reported in the plant. Pyrrolizidine alkaloids are considered to be hepatotoxic and therefore, the use of the plant either as a food or in ethnomedicine need to be restricted. With the availability of primary investigations, further investigations are recommended to study the toxicity of the plant in detail before rationalizing its use as a health food.
\end{abstract}

Keywords: Emilia sonchifolia (L.) DC, traditional use, pharmacological activities, pyrrolizidine alkaloids

\section{INTRODUCTION}

Plants have always remained associated in our life either as a source of medicine or vegetables. Several studies have been shown that vegetables provide a good source of remedy against several diseases and ailments. Dietary antioxidants such as flavonoids and polyphenols have attracted the attention of the researchers since they can protect the body from oxidative stress, which is regarded as prime cause of several deadly diseases including ageing, cardiovascular diseases and cancer ${ }^{1}$.

Emilia sonchifolia (L.) DC (Family: Asteraceae), commonly known as 'lilac tasselflower' is an annual herb with erect or prostrate at base and up to $10-150 \mathrm{~cm}$ tall. It often branches from the very base, usually purplish-green and deep rooting. The leaves $(4-16 \mathrm{~cm} \times 1-8 \mathrm{~cm})$ are sessile, with alternate arrangement, dark green above and lighter green or tinged with purple beneath, and more or less irregularly coarsely dentate. The inflorescence is a terminal head and few together in slender corymbs or rarely solitary. The flowers are orange, pink, purple and white in colour. The fruit is one seeded $(2.5-3.0 \mathrm{~mm})$, linear oblongoid, soft and brown in colour. The plant occurs frequently as a weed in grassy fields, roadsides or in croppy fields and teak forests, ascending up to $1,350 \mathrm{~m}$ in the hills ${ }^{2,3}$.

\section{TRADITIONAL USES}

In Malaysia, the plant is commonly known as 'Setumbak merah' and contributes to one of the popular ingredients of traditional vegetable salads 'Ulam'. The plant is sold in local markets as an edible wild vegetable. The flowers are fried with batter and the leaves eaten $\operatorname{raw}^{4,5}$. The leaves are edible and used as a traditional salad in Bangladesh ${ }^{6}$. In India, the fresh stems and leaves are eaten as a salad or cooked as vegetable ${ }^{7}$. It is considered to be one among the "Ten Sacred Flowers' of Kerala state in India, collectively known as 'Dasapushpam' ('Dasa' means ten and 'pushpam' means flowers) which are predominately used by the traditional healers in treating cancer and other malignant conditions ${ }^{8}$.

The plant is documented in ethnomedicine to possess medicinal benefits in treating diarrhoea, night blindness and sore throat ${ }^{9,10}$, rashes, measles, inflammatory diseases, eye and ear ailments ${ }^{11}$, fever ${ }^{12,13}$, stomach tumor $^{14}$, malaria ${ }^{15}$, asthma ${ }^{12,16,17}$, liver diseases ${ }^{18}$, eye inflammation $^{19}$, earache ${ }^{20}$ and chest pain ${ }^{21}$. In China, the leaves are used for the treatment of dysentery and roundworm infestations, wounds and abscesses, influenza, burns and snake bites ${ }^{22,23}$. In India, the leaf paste in doses of one spoonful once a day at bed time for about 2-3 months is recommended to treat night blindness ${ }^{24}$. The crushed leaves are used externally to treat breast abscesses among tribal women. The leaves are rubbed on the forehead to relieve headache ${ }^{25}$. The Africans consume the leaves as vegetable for its laxative property. The plant has been documented in the Nigerian folk medicine for the treatment of epilepsy in infants ${ }^{26,27}$.

In addition to its several traditional uses, E. sonchifolia is also listed in Ayurveda and Siddha system of medicine. 
Ayurveda recommends the plant for treatment of gastropathy, diarrhoea, ophthalmia, nyctalopia, cuts and wounds, intermittent fevers, pharyngodyma and asthma ${ }^{28}$. In Siddha system of medicine, the plant is recommended for treating intestinal worms and bleeding piles $^{2}$.

\section{PHYTOCHEMICAL STUDIES}

A few chemical constituents have been reported from this plant. The aerial parts afforded two pyrrolizidine alkaloids, identified as senkirkine and doronine ${ }^{29}$. Srinivasan and Subramanian ${ }^{30}$ reported presence of quercetin quercitrin, rutin, kaempferol 3- $\beta$-D-galactoside, ursolic acid, n-hexacosanol and triacontane in the aerial parts. The ethyl acetate fraction of $90 \%$ ethanolic extract of aerial parts yielded rhamnetin, isorhamnetin, luteolin, tricin-7-O-beta-D-glucopyranoside, 8-(2"-pyrrolidinone5"-yl) -quercetin, 5, -2', 6'-trihydroxy-7, 8dimethoxyflavone-2'-O-beta-D-glucopyranoside, succinic acid, fumaric acid, p-hydroxybenzoic acid, 4-hydroxy isophthalic acid, 3, 4-dihydroxycinnamic acid, esculetin, isowedelolactone and uracil respectively ${ }^{11}$. A new cyclohexylacetic acid derivative, named 2-\{4-hydroxy-7oxabicyclo [2.2.1] heptanyl $\}$-acetic acid together with a known analogue, 2-(1,4-dihydroxy cyclohexanyl)-acetic acid was reported from the aerial parts ${ }^{31}$.

Presence of a flavone glycoside, characterized as 5, 7, 8trihydroxy-6, 4'-dimethoxy flavone-7-O- $\alpha$-Lrhamnopyranosyl- $1 \rightarrow 4$ )-O- $\beta$-D-xylopyranosyl- $(1 \rightarrow 4)$ -

galactopyranoside was reported from the stems along with three known compounds Kaempferol 3-O- $\alpha-\mathrm{L}-$ rhamnopyranosyl- $(1 \rightarrow 2)-\beta$-D-glucopyranoside,

Mearnsetin-3-O- $\alpha$-L-rhamnopyranoside and Gehuain (isoflavone) respectively ${ }^{32}$. Gao et al. ${ }^{33}$ isolated simiral, beta-sitosterol, stigmasterol, and palmitic acid from the whole plant. Yadava and $\mathrm{Raj}^{34}$ reported presence of flavone glycoside 3,7,3',4'-tetrahydroxy-flavone-3-O- $\beta$ D-xylopyranosyl- $(1 \rightarrow 3)$-O- $\beta$-D-galactopyranosyl- $(1 \rightarrow 4)$ O- $\alpha$-L-rhamnopyranoside along with two other known compounds Luteolin-7-O- $\beta$-D-glucoside and Isoetin 5'methyl ether in the seeds.

\section{PHARMACOLOGICAL ACTIVITIES}

Due to its several ethnomedicinal uses, E. sonchifolia has been investigated for a good number of pharmacological activities.

\section{Antimicrobial activity}

The methanol extract and its fractions with chloroform, diethyl ether, ethyl acetate and butanol from the aerial parts were studied against 20 bacterial species, 3 yeast species, and 12 filamentous fungi at $10 \mathrm{mg} / \mathrm{ml}$ concentrations $^{35}$. The results of the study revealed antibacterial activity of E. sonchifolia extract and its fractions against Staphylococcus aureus, Pseudomonas aeruginosa, Citrobacter freundii, Escherichia coli, Acinetobacter calcoaceticus, Acinetobacter anitratus, Bacillus licheniformis, Micrococcus spp, Staphylococcus epidermidis, Erwinia spp, Bacillus cereus, Serratia marcescens, Staphylococcus saprophyticus, Yersinia enterocolitica, Shigella sonnei, Morganella morganii and Enterobacter aerogenes. The test samples were also active against yeast species Candida albicans and Cryptococcus neoformans. However, they were ineffective against the bacteria Salmonella typhi, Klebsiella pneumonia and Bacillus subtilis, yeasts Rhodotorula rubra and fungi Rhizophus spp., Fusarium spp., Penicillium spp, Mucor spp, Trichoderma viride, Trichophyton rubrum, Microsporum canis, Trichophyton mentagrophytes, Fusarium oxysporium , Aspergillus flavus, Aspergillus niger and Microsporum gypseum respectively.

In another study, the flavonoid fraction showed stronger antibacterial activity against Staphylococcus aureus in the concentration of $0.8 \mathrm{~g} / \mathrm{ml}$ and weaker antibacterial activity against Escherichia coli and Bacillus subtilis ${ }^{36}$. The alkaloidal fraction also revealed antibacterial activity to Escherichia coli, Bacillus subtilis and Staphylococus aureus when the concentrations of the alkaloids were in the range of $600-800 \mathrm{mg} / \mathrm{ml}^{37}$.

\section{Antiviral activity}

Yadava and $\mathrm{Raj}^{34}$ reported the antiviral activity of the isolated flavones glycoside 3,7,3',4'-tetrahydroxyflavone-3-O- $\beta$-D-xylopyranosyl- $(1 \rightarrow 3)-O-\beta-D-$

galactopyranosyl- $(1 \rightarrow 4)-\mathrm{O}-\alpha$-L-rhamnopyranoside against Japanese Encephalitis Virus in vitro (Vero cells). The compound showed $50 \%$ antiviral activity at $62.5 \mu \mathrm{g} / \mathrm{ml}$.

\section{Analgesic and anti-inflammatory activities}

The aqueous extract of E. sonchifolia is reported to possess more promising anti-inflammatory activity than the methanol extract ${ }^{38}$. In a study, Essien et al. ${ }^{39}$ reported the anti-inflammatory and analgesic activities of the methanol extract of the leaves. The $\mathrm{LD}_{50}$, preliminary phytochemical screening, anti-inflammatory and analgesic activities were investigated using carrageenan, egg albumin, capsaicin-induced paw oedema, formalininduced paw licking, acetic acid induced writhing and hot plate nociception in mice. The $\mathrm{LD}_{50}$ (i. p.) was found to be $2874.02 \mathrm{mg} / \mathrm{kg}$. The preliminary phytochemical screening revealed presence of terpenes, tannins, flavonoids, saponins and alkaloids. The extract demonstrated dose dependent inhibition of the inflammation and nociception in mice.

The antinociceptive activity of hydroethanolic extract from aerial parts was evaluated in mice by Couto et al..$^{40}$ using chemical and thermal models of nociception. The results revealed significant antinociceptive activity at 100 and $300 \mathrm{mg} / \mathrm{kg}$, p.o. in all tests with an observation of more promising effect than morphine. Further, the antinociceptive effect was completely inhibited by the extract at $100 \mathrm{mg} / \mathrm{kg}$, after administration naloxone, indicating the extract possess opioid mediated antinociceptive activity. The extract was further subjected 
to HPLC analysis which revealed the presence of phenolic compounds.

In another study, Rahman et $a l .{ }^{41}$ investigated the analgesic and anti-inflammatory effects of Ageratum conyzoides and E. sonchifolia alcoholic extracts in animal models. Analgesic effects were investigated in mice using acetic acid induced writhing model and formalin induced licking model. The anti-inflammatory effect was studied in rats using carrageenan induced paw edema model. The study demonstrated significant analgesic and inflammatory activities of $E$. sonchifolia extract.

\section{Anticancer activity}

Search for anticancer factor from plants always remained a potential area of investigation. In an in vitro study, it was observed that the methanol extract of E. sonchifolia is cytotoxic to Daltons lymphoma (DL), Ehrlich ascites carcinoma (EAC) and mouse lung fibroblast (L-929) cells, but non toxic to normal human lymphocytes. Further, the extract at $100 \mathrm{mg} / \mathrm{kg}$, p.o., in mice decreased the development of both solid and ascites tumors with an increase in the life span. The extract also inhibited DNA synthesis ${ }^{42}$. As a continuation to the research, Shylesh et $a l .{ }^{43}$ reported the anticancer activity of an active terpene fraction, isolated by TLC from the n-hexane extract of $E$. sonchifolia in mice using Dalton's lymphoma ascitic (DLA) cells. Cytotoxicity of the extract and the isolate to macrophages, thymocytes and DLA cells was measured using MTT assay, DNA ladder assay and DNA synthesis in culture. Short term toxicity evaluation of the active fraction was also carried out in mice. Results of the study revealed that the hexane extract was most active and it showed in vitro cytotoxicity to DLA and thymocytes, but not to the macrophages. The extract induced membrane blebbing, nuclear condensation, DNA ladder formation and formation of apoptotic bodies which are characteristic to apoptotic cell death. On the other hand, the n-hexane fraction protected $50 \%$ of mice challenged intraperitoneally with 106 DLA cells. The active terpene fraction induced cell-specific apoptosis.

Cibin et al. ${ }^{44}$ reported the antioxidant and antitumor properties of the flavonoid fraction isolated from the whole plant of E. sonchifloia. The ability of the flavonoid fraction to inhibit $\mathrm{Cu}^{2+}$ induced lipoprotein oxidation in human serum and superoxide production was measured to assess the antioxidant property in comparison to quercetin. The results revealed potent antioxidant and anticancer effects of the flavonoids present in the plant.

A study was conducted to investigate the apoptosis induction and molecular mechanisms in human colorectal cancer cells treated with the methanol extract in vitro ${ }^{45}$. The extract induced cell growth inhibition in a concentration and time dependent manner suggesting that both extrinsic and intrinsic apoptotic pathways may be involved in extract provoked apoptotic death in the cancer cells.
Sophia et al. ${ }^{46}$ reported the effect of n-hexane extract of E. sonchifolia on azaserine (O-diazoacetyl-L-serine)induced pancreatic dysplasia in rats. Results of the study revealed a significant decrease of pancreatic and hepatic enzymatic antioxidants like catalase (CAT), superoxide dismutase (SOD), glutathione-S-transferase (GST), glutathione peroxidase (GPx) and non-enzymatic antioxidants like vitamin $\mathrm{C}$, glutathione (GSH) content, and a significant increase in pancreatic serum amylase and lipase, and levels of hepatic marker enzymes viz. alanine aminotransferase (ALT), aspartate aminotransferase (AST) and alkaline phosphatase (ALP). Treatment with the extract for 16 weeks resulted in a concomitant reduction in pancreatic and hepatic damage.

\section{Antioxidant activities}

A number of antioxidant studies on E. sonchifolia have been carried out by different researchers. In a study, the fresh juice and methanol extract of the leaves were reported to be potent inhibitors of superoxide radical generation and hydroxyl radical formation in vitro. The extract also showed significant anti-inflammatory activity ${ }^{47}$.

Gayathri Devi et al. ${ }^{25}$ studied the protective effects of the flavonoid fraction isolated from the whole plant of $E$. sonchifolia on perchlorate-induced oxidative damage in female albino rats. The level of TBARS, catalase, SOD, glutathione reductase (GR), glutathione peroxidase (GPx), glutathione-S-transferase (GST) and concentration of reduced glutathione (GSH) were estimated. The results revealed that the flavonoid fraction is a potent inhibitor of peroxidise damage.

An in vitro study was conducted to evaluate the free radical scavenging activities of n-hexane extract of the whole plant ${ }^{48}$. The extract was evaluated for DPPH radical, superoxide radical and hydrogen peroxide scavenging activity. The results of the study indicated potential antioxidant effect of the extract. Further, the HPTLC analysis of the extract revealed presence of terpenoids. The same group of researchers, in another study investigated the protective effect of E. sonchifolia against oxidative stress in rats induced by high protein diet $^{49}$. The test animals were fed with high protein diet (100\% raw soya flour) for one month along with n-hexane extract at $250 \mathrm{mg} / \mathrm{kg}$, p.o. The extract significantly prevented the increase in lipid peroxidation with increase in the levels of CAT, SOD, GPx, GSH, GST and vitamin C. Again in another study, the efficacy of the n-hexane extract was examined against ethanol induced pancreatic dysfunction in rats. The extract successfully reduced the pancreatic enzymatic antioxidants SOD, catalase, lipid peroxidation, glutathione peroxidase, glutathione and vitamin C. Histopathological examination showed normal architecture of the pancreas against the damage induced by ethanol ${ }^{50}$.

Sophia et $a .^{51}$ examined the enzymatic and nonenzymatic antioxidant levels in the whole plant of $E$. sonchifolia and found that the plant possesses 
predominant amount of enzymatic antioxidants like SOD, catalase, GPx, ascorbate oxidase, GST, peroxidase and non-enzymatic antioxidants such as total reduced vitamin $\mathrm{C}$ and glutathione. The study inferred that the plant may be considered as a promising source of natural antioxidants.

As a continuation to earlier work, Sophia et al. ${ }^{52}$ investigated the effect of oral administration of the nhexane extract for 30 days on the extent of oxidative damage and changes in the histopathological and biochemical parameters in the pancreas of the rats fed high protein diet. The results demonstrated significant increase in serum levels of amylase, lipase, AST, ALT, urea, uric acid, creatinine, tissue DNA and RNA content and showed a significant decrease in the pancreatic antioxidants, indicating E. sonchifolia as a pancreatoprotective herb.

$\mathrm{Raj}^{32}$ reported the antioxidant activity of the isolated flavones glycoside5, 7, 8-trihydroxy-6, 4'-dimethoxy flavone-7-O- $\alpha$-L-rhamnopyranosyl- $1 \rightarrow 4$ )-O- $\beta$-D-

xylopyranosyl- $(1 \rightarrow 4)$-galactopyranoside. The compound showed potent antioxidant activity.

\section{Anti-diabetic activity}

The effects of the aqueous extract of E. sonchifolia on glucose concentration and liver function enzymes were assessed by Comfort et al..$^{53}$. The results demonstrated that the aqueous extract could decrease the blood glucose level and demonstrated hepatoprotective effects in experimental diabetes.

In another study, the antidiabetic and antilipidemic effects of the alkaloidal fraction in dithizone induced diabetic rats were assessed. The results of the study also revealed significant reduction in the blood glucose, cholesterol and triacylglycerol levels ${ }^{54}$.

\section{Hepatoprotective effects}

The effect of ethanol extract of the leaves on the haematological parameters and histomorphology of the liver of mice infected with Plasmodium berghei berghei was reported by Edagha et al. ${ }^{55}$. The results indicated that the extract promotes erythropoiesis at $325 \mathrm{mg} / \mathrm{kg}$, and haemolytic at $650 \mathrm{mg} / \mathrm{kg}$, mild toxic effect on histopathology at $325 \mathrm{mg} / \mathrm{kg}$ but also appeared to offer hepatoprotective effect in infected mice.

\section{Neurobehavoural effects}

Edagha et al. ${ }^{56}$ reported the effects of ethanol extracts from the leaves of Nauclea latifolia and E. sonchifolia on anxiety, fear and locomotion in mice infected with Plasmodium berghei berghei. The mice were first infected with the parasite intraperitoneally followed by oral administration of the extracts for five days. Behavioural tests were performed on pre-treatment and post-treatment of the parasites. The results indicated that the extracts are effective in reducing anxiety and fear and enhance locomotion in the infected mice.

\section{Anti-cataract activities}

An in vivo study was performed to investigate the modulatory effects of the flavonoids against selenite cataract by Lija et al. ${ }^{57}$. The study was carried out based on the earlier reports that the flavonoid fraction contributed a significant antioxidant activity. The results revealed that the flavonoid fraction increased the activities of SOD, catalase and reduced glutathione, suggesting that the flavonoids can modulate lens opacification and oxidative stress in selenite induced cataract.

\section{Anticonvulsant activity}

Asijea et al. ${ }^{58}$ reported the anticonvulsant activity of the ethanol, chloroform and aqueous extracts from the leaves of E. sonchifolia in chicks and mice through maximal electroshock and strychnine induced seizures. The aqueous extract revealed promising anticonvulsant effect compared to other extracts under the study. The research findings agreed upon the ethnomedicinal use of the aqueous leaf extract in treating infantile convulsion by the traditional healers in Nigeria.

\section{CONCLUSION}

The phytochemical examination of E. sonchifolia revealed presence of a wide range of chemical constituents that are responsible for its promising multidimensional pharmacological activities, such as antimicrobial, analgesic, anti-inflammatory, antioxidant, anticancer, antidiabetic, hepatoprotective, antianxiety, anticataract and anticonvulsant activities. However, the main concern is the presence of pyrrolizidine alkaloids, since the plant is considered edible and used primarily as an ingredient in salads in many countries including Malaysia. Pyrrolizidine alkaloids are believed to be hepatotoxic. They cause irreversible hepatic damage and toxicity signs are a consequence of impaired liver function. Thus, its use either as a food or in ethnomedicine need to be restricted. With the availability of primary investigations, further investigations are recommended to study the toxicity of the plant in detail before rationalizing its use as a health food.

\section{REFERENCES}

1. Nayeem K, Godad, Hashilkar N and Joshi RK. Gastroprotective activity of the aqueous extract from the roots of Daucus carota L. in rats. Int J Res Ayurveda Pharm 2010; 1: 112-119.

2. Khare CP. Emilia sonchifolia (L.) DC. Indian Medicinal Plants: An Illustrated Dictionary. Springer-Verlag, Berlin Heidelberg; 2007. p.01.

3. http://www.globinmed.com. Globinmed: Emilia sonchifolia (L.) DC. (accessed 8th May 2015).

4. Mathews J, Yong KK and Nurulnahar BE. Preliminary investigation on biodiversity and its ecosystem in oil palm plantation. Proceedings of Agriculture, Biotechnology \& Sustainability Conference, Palm oil: Empowering Change (PIPOC 2007), Malaysian Palm oil Board, Ministry of Plantation industries and commodities, Malaysia; 2007. p. 1112-1159. 
5. http://www.malaysiavegetarianfood.com. Simple Malaysian Vegetarian Food (accessed 8th May 2015).

6. Motaleb MA, Hossain MK, Alam MK, Mamun MMAA and Sultana M. Commonly used medicinal herbs and shrubs by traditional herbal practitioners: Glimpses from Thanchi upazila of Bandarban. IUCN (International Union for Conservation of Nature), Dhaka; 2013. p. 77-78.

7. http://www.stuartxchange.com. Phillipine Medicinal Plants: Tagulinaw (accessed 9th May 2015).

8. Arun Raj GR, Shailaja U, Rao Prasanna N, Sharanesh, T and Gokul J. Review on the contribution of Dashapushpa, a traditional medicine in the management of cancer. Global J Res Med Plants \& Indigenous Med 2013; 2: 656-663.

9. Ghani A. Medicinal plants of Bangladesh: Chemical constituents and uses. Asiatic Society of Bangladesh, Dhaka; 1998. p. 460-461.

10. Ahmed ZU, Hassan MA, Begum Z NT, Khondker M, Kabir SMH, Ahmed M, Ahmed ATA, Rahman AKA and Haque EU: In: Encyclopedia of Flora and Fauna of Bangladesh, Vol. 8 . Angiosperms: Dicotyledons (Fabaceae-Lythraceae). Asiatic Society of Bangladesh, Dhaka; 2009. p. 40-41.

11. Shen SM, Shen LG, Lei QF, Si JY, Liu CM and Lu H. Chemical constituents contained in aerial parts of Emilia sonchifolia. Zhongguo Zhong Yao Za Zhi 2012; 37: 3249-3251.

12. Zani CL, Chaves PPG, Queiroz R, De Oliveira AB, Cardoso JE, Anjos AMG and Grandi TSM. Brine shrimp lethality assay as a prescreening system for anti-trypanosoma cruzi activity. Phytomedicine 1995; 2: 47-50. http://dx.doi.org/10.1016/S09447113(11)80048-6

13. Brandao M, Botelho M and Krettli E. Antimalarial experimental chemotherapy using natural products. Cienc cult 1985; 37: 11521163.

14. Mohiduddin M, Alam MK, Basak SR and Hossain MK. Ethnomedico botanical study among four indigenous communities of Bandarban, Bangladesh. Bangladesh J Plant Taxon 2012; 19: 45-53.

15. Kohler I, Jenett siems K, Kraft C, Siems K, Abbiw D, Bienzle U and Eich E. Herbal remedies traditionally used against malaria in Ghana: bioassay-guided fractionation of Microglossa pyridolia (Asteraceae). Z Naturforsch Ser C 2002; 57c: 1022-1027.

16. Panthong A, Kanjanapothi D and Taylor WC. Ethnobotanical review of medicinal plants from Thai traditional books, Part 1: Plants with antiinflammatory, antiasthmatic and antihypertensive properties. J Ethnopharmacol 1986; 18: 213-228. http://dx.doi.org /10.1016/0378-8741(86)90001-2

17. Jain SP, Singh SC and Puri HS. Medicinal plants of Neterhat, Bihar, India. Int J Pharmacog 1994; 32: 44-50. http://dx.doi.org $/ 10.3109 / 13880209409082971$

18. Yanfg LL, Yen KY, Kiso Y and Kikino H. Antihepatotoxic actions of Formosan plant drugs. J Ethnopharmacol 1987; 19: 103-110. http://dx.doi.org/10.1016/0378-8741(87)90142-5

19. Singh VP, Sharma SK and Khare VS. Medicinal plants from Ujjain district Madhya Pradesh - Part II. Indian Drugs 1980; 5: 7-12.

20. Manandhar NP. An ethnobotanical survey of herbal drugs of Kaski district, Nepal. Fitoterapia 1994; 65: 7-13.

21. Parkash JW, Raja RDA, Anderson NA, Williams C, Regini GS, Bensar K, Rajeev R, Kiruba S, Jeeva S and Das SMS Ethnomedicinal plants used by Kani tribes of Agasthiyarmalai biosphere reserve, Southern Western Ghats. Indian J Trad Knowledge 2008; 7: 410-413.

22. Galinato MI, Moody K and Piggin CM. Upland rice weeds of south and south East Asia. International Rice Research institute, Los Banos; 1999. p. 22-23.

23. Josh K. Boban Tribal ethnomedicine. Continuity and change. APH Publishing Corporation, New Delhi; 1998. p. 174,178, 181.

24. Satyavathi K, Satyavani S, Padal TSN and Padal SB. Ethnomedicinal plants used by primitive tribal of Pedabayalu Mandalam, Visakhapatnam district, A. P, India. Int J Ethnobiol Ethnomed 2014; 1: 1-7.

25. Gayathri Devi D, Lija Y, Cibin TR, Biju PG, Gayathri Devi V and Abraham A. Evaluation of protective effects of Emilia sonchifolia Linn. (DC.) on perchlorate-induced oxidative damage. J Biol Sci 2006; 6: 887-892. http://dx.doi.org/10.3923/jbs.2006.887.892

26. Adesina SK. Studies on a Nigerian herbal anticonvulsant recipe. Int J Crude Drug Res 1982; 20: 93-100. http://dx.doi.org/10.3109 $/ 13880208209083295$

27. Gill LS, Nyawuame HGK, Esezebor EI and Osagie IS. Nigerian Folk Medicine: Practices and believes of Esan people. Benin (Nigeria): University of Benin Press, Benin; 1993. p. 1-20.
28. Nair SL, Chopra RN. In: Glossary of Indian Medicinal Plants. National Institute of Science and Communication, New Delhi; 1996 p. 107.

29. Cheng D and Röder E. Pyrrolizidine alkaloids from Emilia sonchifolia. Planta Med 1986; 6: 484- 486 http://dx.doi.org/10.1055/s-2007-969260

30. Srinivasan KK and Subramanian SS. Chemical investigation of Emilia sonchifolia. Fitoterapia 1980; 51: 241-243.

31. Shen S, Shen L, Lei Q, Zhang J, Li G and Si J. A new cyclohexylacetic acid derivative from the aerial parts of Emilia sonchifolia. Nat Prod Res 2013; 27: 1330-1334. http://dx.doi.org/10.1080/14786419.2012.738205

32. Raj M. Natural antioxidant (Flavone glycoside) from Emilia sonchifolia DC. and its potential activity. Int J Pharm PharmSci 2012; 4: 159-162.

33. Gao JJ, Cheng DL and Liu XP. Chemical constituents of Emilia sonchifolia L. DC. Zhongguo Zhong Yao Za Zhi 1993; 18: 102-103.

34. Yadava RN and Raj M. Antiviral activity of a new flavones glycoside from Emilia sonchifolia DC. Indian J Chem 2012; 51B: 635-638.

35. Yoga Latha L, Darah I, Sasidharan S and Jain K. Antimicrobial activity of Emilia sonchifolia DC., Tridax procumbens L. and Vernonia cinerea L. of Asteracea family: Potential as food preservatives. Malaysia J Nutr 2009; 15: 223-231.

36. Chen X, Wei Y, Zhou W, Pan M, Li J and Shipin K. Study on separations and the antimicrobial effects of the total flavonoids of Emilia sonchifolia. Food Sci Tech 2009; 1: 163-165.

37. Zhou W, Wei Y, Li J, Yan L and Lai X. Study on extraction and antibacterial activities of the alkaloids in Emilia sonchifolia from Guangxi Lishizen Med Materia Med Res 2008; 8 .

38. Muko KN and Ohiri FC. A preliminary study on the antiinflammatory properties of Emilia sonchifolia leaf extracts. Fitoterapia 2000; 71: 65-68. http://dx.doi.org/10.1016/S0367326X(99)00123-9

39. Essien GE, Nwidu LL and Nwafor PA. Anti-Inflammatory and analgesic potential of methanolic extract of Emilia sonchifolia (Compositae) leaves in rodents. Afr J Biomed Res 2009; 12: 199207.

40. Couto VM, Vilela FC, Dias DF, Dos Santos MH, Soncini R, Nascimento CG and Giusti-Paiva A. Antinociceptive effect of extract of Emilia sonchifolia in mice. J Ethnopharmacol 2011; 134: 348-353. http://dx.doi.org/10.1016/j.jep.2010.12.028

41. Rahman MA, Akter N, Rashid H, Ahmed NU, Uddin N and Islam MS. Analgesic and anti-inflammatory effect of whole Ageratum conyzoides and Emilia sonchifolia alcoholic extracts in animal models. African J Pharm Pharmacol 2012; 6: 1469-1476.

42. Shylesh BS and Padikkala J. In vitro cytotoxic and antitumour property of E. Sonchifolia (L) DC in mice. J Ethnopharmacol 2000; 73: 495-500. http://dx.doi.org/10.1016/S0378-8741(00)00317-2

43. Shylesh BS, Nair SA and Subramoniam A. Induction of cellspecific apoptosis and protection from Dalton's lymphoma challenge in mice by an active fraction from Emilia sonchifolia. Indian J Pharmacol 2005; 37: 232-237. http://dx.doi.org/10.4103/ 0253-7613.16569

44. Cibin TR, Srinivas G, Gayathri Devi D, Srinivas P, Lija Y and Abraham A. Antioxidant and antiproliferative effects of flavonoids from Emilia sonchifolia Linn on human cancer cells. International J Pharmacol 2006; 2: 520-524. http://dx.doi.org/10.3923 /ijp.2006.520.524

45. Lan YH, Chiang JH, Huang WW, Lu CC, Chung JG, Wu TS, Jhan JH, Lin KL, Pai SJ, Chiu YJ, Tsuzuki M and Yang JS. Activations of both extrinsic and intrinsic pathways in HCT 116 human colorectal cancer cells contribute to apoptosis through p53-mediated ATM/Fas signaling by Emilia sonchifolia extract, a folklore medicinal plant. Evidence-Based Complementary and Alternative Medicine (Online) published 2012, http://dx.doi.org/ $10.1155 / 2012 / 178178$

46. Sophia D, Ragavendran P, Arul Raj C and Gopalakrishnan VK Protective effect of Emilia sonchifolia on azaserine-induced pancreatic dysplasia. J Acute Med 2014; 4: 68-74. http://dx.doi.org/ 10.1016/j.jacme.2014.02.003

47. Shylesh BS and Padikkala J. Antioxidant and anti-inflammatory activity of Emilia sonchifolia. Fitoterapia 1999; 70: 275-278 http://dx.doi.org/10.1016/S0367-326X(99)00037-4

48. Sophia D, Ragavendran P, Arul Raj C and Gopalakrishnan VK. In vitro antioxidant activity and HPTLC determination of n-hexane extract of Emilia sonchifolia (L.)DC. J Basic Clin Pharm 2011; 2: $179-183$. 
49. Sophia D, Ragavendran P, Arul Raj C and Gopalakrishnan VK. High protein diet induced hepatic oxidative stress and its amelioration by the herb, Emilia sonchifolia (L.) DC. Pharmacologyonline 2011; 1: 149-154.

50. Sophia D, Gomathy M, Shebin T, Ragavendran P, Arul Raj C and Gopalakrishnan VK. Effect of Emilia sonchifolia (Linn.)DC on alcohol-induced oxidative stress in pancreas of male albino rats. Asian Pacific J Trop Med 2011; 4: 973-977. http://dx.doi.org /10.1016/S1995-7645(11)60229-0

51. Sophia D, Ragavendran P, Arul Raj C and Gopalakrishnan VK. Antioxidant properties of Emilia sonchifolia (L.): An in vitro study. J Pharm Res 2012; 5: 1162-1164.

52. Sophia D, Ragavendran P, Arul Raj C and Gopalakrishnan VK. Protective effect of Emilia sonchifolia (L.) against high protein diet induced oxidative stress in pancreas of Wistar rats. J Pharm Bioallied Sci 2012; 4: 60-65. http://dx.doi.org/10.4103/09757406.92735

53. Monago CC and Ogbonnaya AE. Effect of aqueous extract of Emilia sonchifolia on some liver enzyme in dithizone induced diabetes in rabbits. Nigerian J Biochem Mol Biol 2009; 24: 8-15.

54. Monago CC, Gozie GC and Joshua PE. Antidiabetic and Antilipidemic Effects of Alkaloidal Extract of Emilia sonchifolia in Rat. Res J Sci Tech 2010; 2: 51-56.

55. Edagha IA, Davies KG, Akpan BC, Mbadugha CC and Udoiso WU. Ethanolic extract of Emilia sonchifolia leaves possess erythropoietic and hepatoprotective effect in mice infected with Plasmodium Berghei Berghei. OA Maced J Med Sci 2014; 2: 11-17. http://dx .doi.org/10.3889/MJMS.1857-5773.2014.0345

56. Edagha IA, Davies KG, Ita SO, Aquaisua AN and Anwana BE. Preliminary study: Neurobehavioural effects of Nauclea latifolia and Emilia sonchifolia in mice infected with Plasmodium berghei berghei. British J Med MedRes 2015; 5: 914-923. http://dx.doi.org /10.9734/BJMMR/2015/3608

57. Lija Y, Biju PG, Reeni A, Cibin TR, Sahasranamam V and Abraham A. Modulation of selenite cataract by the flavonoid fraction of Emilia sonchifolia in experimental animal models. Phytother Res 2006; 20: 1091-1095. http://dx.doi.org/ $10.1002 /$ ptr. 2005

58. Asijea O, Adelusib SA and Usifohb CO. Anticonvulsant activity of Emilia sonchifolia leaf extracts. Pakistan J Sci Ind Res 2006; 49: 269-275.

\section{Cite this article as:}

Dash Gouri Kumar, Abdullah Mohd. Syafiq and Yahaya Ruhaiyem. Traditional uses, phytochemical and pharmacological aspects of Emilia sonchifolia (L.) Dc. Int. J. Res. Ayurveda Pharm. 2015;6(4):551-556 http://dx.doi.org/10.7897/2277-4343.064103

Source of support: Nil, Conflict of interest: None Declared

Disclaimer: IJRAP is solely owned by Moksha Publishing House - A non-profit publishing house, dedicated to publish quality research, while every effort has been taken to verify the accuracy of the content published in our Journal. IJRAP cannot accept any responsibility or liability for the site content and articles published. The views expressed in articles by our contributing authors are not necessarily those of IJRAP editor or editorial board members. 